EXCERPTED FROM

\title{
Critical Security Studies and World Politics
}

edited by

Ken Booth

Copyright (C) 2005

ISBNs: 1-55587-825-3 hc 1-55587-826-1 pb

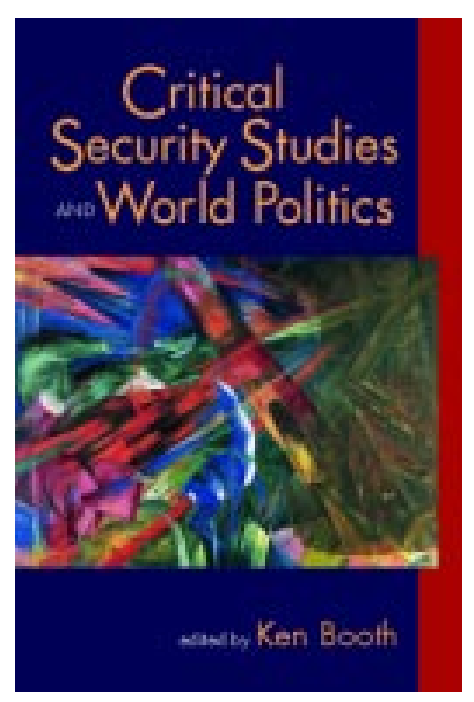

\author{
s \\ LYNNE RIENNER PUBLISHERS \\ 1800 30th Street, Ste. 314 \\ Boulder, CO 80301 \\ USA \\ telephone 303.444.6684 \\ fax 303.444.0824
}

This excerpt was downloaded from the

Lynne Rienner Publishers website

www.rienner.com 


\section{Preface}

The search for security is primordial, and never before in history has human society faced the multidirectional challenges that will predictably develop in the coming decades. Our times demand the very best efforts from those who study security, for world politics today is hounded not only by traditional interstate conflicts but also by nuclear-armed regional threats, ever more innovative and dangerous terrorist strategies, new problems arising from the dynamics of globalization, the challenges of inflamed religious and ideological extremism, the politics of rage provoked by obscene disparities of wealth and opportunity, and all the complexities caused by the momentum of global environmental change. Intense and multilevel insecurity will be in season for the foreseeable future, and so the search for security will be at the top of the agenda in public policy making as well as dominating countless private lives.

Can academic security studies respond to this predictably dangerous future? How should we think about security in this fractious world? What is real? How reliable is our knowledge? What can we do?

We live in an era of question marks about world security, and this volume cannot attempt to give all the answers. Instead, it seeks to offer a more complex picture of the situation as a result of shifting the way security has been conceived in mainstream security studies as the subject area developed in the period since World War II. This alternative approach has been labeled critical security studies (CSS). Although self-consciously new as an academic subject area, CSS has a long and complex ancestry in terms of its social and political ideas. Its impact on the intellectual fortresses of orthodox security studies has so far been limited, but its influence is evident elsewhere, and its key ideas have to be reckoned with by anyone seriously engaging with the theory and practice of security. CSS has established an institutionalized life of its own, with courses and programs in a number of universities, as well as a steadily growing body of research. It has achieved 
an academic presence that exceeds what has been written in its name, being for the moment a subject without much explicit literature. This volume is one attempt to help to fill that gap.

By critically reconsidering complex global insecurities, readers will be better able to pursue their own explorations of how we-the global wemight learn to live together, collectively, with more success than in the past. My hope is that the book will help today's students-so many of whom feel both angry and helpless about the world they have inheritedby explaining that there are different (and more complex) ways of thinking about security than the dismal ideology of political realism. CSS is not, of course, the answer in itself; it is only a field of study, a starting point. It is necessary, at the least, to go beyond academic critical explorations with a more policy-focused eye, and in the concluding chapter I outline a critical theory of security that seeks to turn helplessness into a specific theoretical commitment, anger into a political orientation.

$$
\text { * * * }
$$

In completing this volume, I want to acknowledge the support of Lynne Rienner Publishers. This volume would not have been part of the Critical Security Studies Series without the backing of Lynne Rienner herself. She declined my idea of establishing a journal to promote thinking about critical approaches to security and instead suggested a book series. She had faith-and in the most concrete way. If, in years to come, CSS ceases to be seen merely as an alternative to the political realist orthodoxy of security studies, then the production of relevant literature will have been vital. Good ideas do not spread without people who will back them with material support. Others at Lynne Rienner Publishers include Sally Glover in Boulder, Colorado, and Richard Purslow, LRP's former UK editor. I want to thank them for their professionalism and patience. I wish also to thank two anonymous referees who have helped make this a better book.

The version of CSS that will be elaborated in the introductory and concluding chapters had its origins in the late 1980s in the Department of International Politics at the University of Wales, Aberystwyth. The first master's course entitled "Critical Security Studies" was taught there in 1995 , and I want to thank colleagues and students not only for making such a development possible but also for contributing to the intellectual buzz that has always accompanied it. Crucial to this development, including the teaching of the first course, has been Richard Wyn Jones, whose book Security, Strategy, and Critical Theory was published earlier in this series; he is also a contributor to this volume. Although some of the contributors will not see themselves fully in the embrace of this Welsh School, I believe that there is an important degree of coherence throughout; this is testimony 
to the seriousness with which the contributors undertook their task and wrote to their brief.

For bringing the manuscript together, I want to thank Elaine Lowe once more for her technical skills and Eurwen Booth for a variety of editorial help. Don Henderson deserves thanks for helping with the bibliography. I could not have finished this volume, as departmental chair, without the best support staff in the business; our administrators and secretaries all help to make the Aber International Politics Department the unique place it is.

-Ken Booth 


\section{Ordering Information}

Examination Copies

For books marked with a $\rightarrow$, examination copies are available for $\$ 7.50$. Shipping is included in the price of exam copies.

Please limit your request to three books. submit the order on department letterhead, and include the name and number of the course, it anticipated enrollment, when it will be offered and the book you are currently using.

\section{Desk Copies}

We provide desk copies on request to faculty who have adopted an LRP title as a required text in a course, providing the bookstore orders 10 or more copies from LRP. Please include the instructor's name and course enrollment in the request

Wholesale and Retail Returns

Books may be returned for full credit within 12 months of invoice date if they are in clean,

saleable condition and a copy of the invoice or the invoice number is included with the return.

All returns must be shipped to our warehouse:

Lynne Rienner Publishers, Inc.

c/o Books International

22883 Quicksilver Drive

Dulles, VA 20166

Questions

Please contact the LRP Customer Service Department at cservice@ rienner.com or at (303) 444-6684 with questions or concerns about your order

Prices subject to change without notice. Please allow three weeks for delivery of books in stock.

\section{To place an order in Europe}

Please send orders to:

Lynne Rienner Publishers

3 Henrietta Street • Covent Garden

London WC2E 8LU • UK

Freephone (UK residents only): 0800-526-830 Call: (44) 207-240-0856

Fax: (44) 207-379-0609

E-mail: orders@edspubs.co.uk

Payments must be in $\mathfrak{f s}$ sterling and checks made payable to EDS Publications Ltd. Visa, Mastercard and American Express are also accepted. Due to currency fluctuations $f$ accepted. Due to currency fluctuations $£$
prices are subject to change without notice.

Please add shipping as follows:

$\begin{array}{lrr} & \text { One Book } & \text { Each Adth Book } \\ \text { UK } & £ 2.00 & £ 1.00 \\ \text { Europe } & £ 4.00 & £ 1.00\end{array}$

For information on academic inspection copies, contact Imogen Adams at the LRP London address above.
Speed your order:

Call: (303) 444-6684

Fax: (303) 444-0824

Visit: www.rienner.com

1.

Ship to (please print legib/y):

Name:

Address:

City/State/Zip Code:

(Please include your 4-digit zip code extension.)

Country:

Fax:

Telephone:

2.

Method of Payment (orders from individuals must be prepaid):

Check enclosed (U.S. \$, drawn on a U.S. bank, payable to Lynne Rienner Publishers)

$\square$ Charge my credit card: ஏ VISA $\square$ MasterCard

Card No. Exp.

Signature

- Purchase Order enclosed (please attach to this order form)

3.

I wish to order the following items:

ISBN (last 6 digits) Qty Author \& Title

Price Total

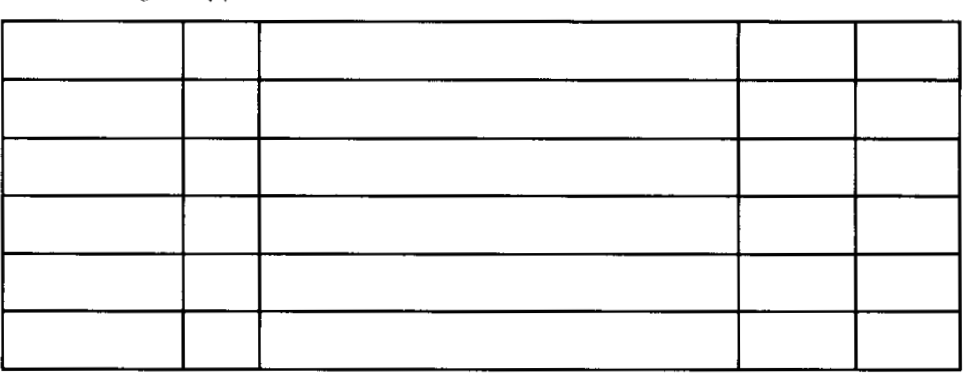

\begin{tabular}{|c|c|c|}
\hline \multicolumn{3}{|c|}{ Postage Rate Chart } \\
\hline & One Book & Each Adth Book \\
\hline $\begin{array}{l}\text { U.S., Canada, } \\
\text { and Mexico }\end{array}$ & $\$ 3.75$ & $\$ 1.00$ \\
\hline \multicolumn{3}{|c|}{ Europe: see box at left. } \\
\hline $\begin{array}{r}\text { All Other Areas: } \\
\square \text { Surface - } \\
\square \text { Airmail - }\end{array}$ & $\begin{array}{l}\$ 5.00 \\
\$ 12.00\end{array}$ & $\begin{array}{l}\$ 2.00 \\
\$ 5.00\end{array}$ \\
\hline \multicolumn{3}{|c|}{ Remember, postage is included in the price of exam copies } \\
\hline
\end{tabular}

Subtotal

Colorado residents add $3 \%$ sales tax

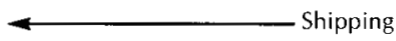

TOTAL 